\title{
КЛІНІЧНИЙ ПЕРЕБІГ ПОДАГРИ У ВІЙСЬКОВОСЛУЖБОВЦІВ НА СУЧАСНОМУ ЕТАПІ
}

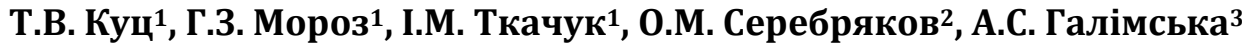 \\ 1 Українська військово-медична академія, м. Київ, Україна \\ 2 Житомирський військовий госпіталь, м. Житомир, Україна \\ ${ }^{3}$ Рівненський військовий госпіталь, м. Рівне, Украӥна
}

\begin{abstract}
Мета: провести комплексний аналіз клінічних проявів подагри у військовослужбовців Збройних Сил України (за даними з історій хвороби пацієнтів кардіоревматологічного відділення Національного військово-медичного клінічного центру «Головний військовий клінічний госпіталь» (НВМКЦ «ГВКГ»).

Матеріали і методи. Методом випадкової вибірки проведено аналіз 103 історій хвороби 92 пацієнтів чоловічої статі кардіоревматологічного відділення НВМКЦ «ГВКГ» з діагнозом подагра, віком від 27 до 58 років. Для дослідження вікових особливостей перебігу подагри пацієнти були розділені на дві групи: I група - до 45 років (молодий вік) 40 хворих; II група - 46-58 років (середній вік) 52 хворих. За результатами дослідження сформована комп'ютерна база даних. Статистична обробка проводилась з використанням програми Microsoft Excel 2007 та стандартного статистичного пакета STATISTICA 6,0.

Результати. Ураження першого плеснофалангового суглоба на момент госпіталізації

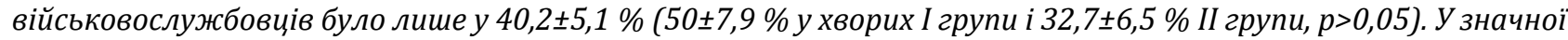
частини хворих визначено ураження колінних $(23,9 \pm 4,4 \%)$ та гомілковостопних суглобів $(20,7 \pm 4,2 \%)$. Характерним $\epsilon$ поєднане ураження суглобів, зокрема, першого плеснофалангового суглоба, та інших суглобів, яке спостерігалось у 20,7士7,5 \% військовослужбовців в дебюті подагри. Діагноз подагри був

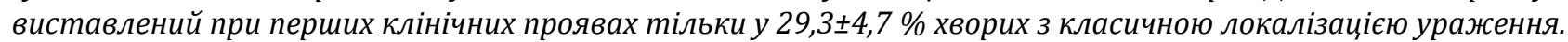
У більшості хворих на подагру діагностовано ураження нирок, зокрема, хронічна ниркова недостатність

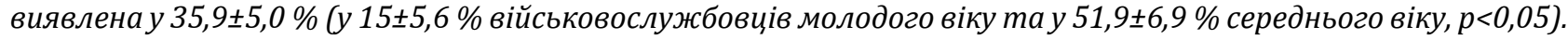

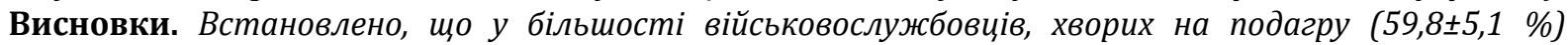
характерною була атипова локалізація ураження суглобів, часте поєднання ураження першого плеснофалангового та інших суглобів. При перших клінічних проявах подагра була діагностована тільки у 29,3ะ4,7 \% хворих. Ураження нирок виявлено у більшості хворих на подагру.
\end{abstract}

Ключові слова: подагра, суглобовий синдром, клінічні прояви подагри.

Вступ. Подагра залишається однією 3 важливих проблем сучасної клінічної практики $[1,2,3]$. Дослідження останніх років підтвердили швидкі темпи зростання частоти гіперурикемії та подагри у світовій популяції, що може бути зумовлене зміною характеру харчування, зростанням частоти ожиріння та гіпертонічної хвороби, застосуванням препаратів, що підвищують рівень сечової кислоти (ацетилсаліцилової кислоти, тіазидних діуретиків) [1, 2, 4]. У Мадриді на Конгресі Європейської протиревматичної ліги (European League Against Rheumatism, EULAR) в 2013 році був зроблений висновок, що подагра - це два різних захворювання, одне 3 яких $\epsilon$ метаболічним і проявляється гіперурикемією (iï ще називають «хімічною подагрою»), а другий компонент подагри - це власне типове запалення суглобів внаслідок відкладання в тканинах кристалів моноурату натрію [5]. Лише у 20 \% пацієнтів гіперурикемія реалізується в подагру. Загалом поширеність подагри становить серед дорослого населення $1-6,8 \%$ [6]. Характерним є збільшенням чисельності хворих молодого віку. В Україні поширеність подагри становить $0,4 \quad \%$ дорослого населення. Пік захворюваності у чоловіків припадає на вік 35-50 років, у жінок - 55-70 років [1]. Подагра $\epsilon$ найпоширенішим запальним захворюванням суглобів у чоловіків. Актуальною ця проблема $\epsilon$ і для військової медицини [7]. Проте в науковій літературі відсутні дані щодо особливостей розвитку та перебігу подагри у військовослужбовців на сучасному етапі, що i обумовило необхідність проведення нашого дослідження.

\section{Мета}

дослідження. Провести комплексний аналіз клінічних проявів подагри у військовослужбовців Збройних Сил України (за даними з історій хвороби пацієнтів кардіоревматологічного відділення Національного військово-медичного клінічного центру «Головний військовий клінічний госпіталь» (НВМКЦ «ГВКГ»).

Матеріали та методи дослідження. Методом випадкової вибірки проведено аналіз 103 історій хвороби 92 пацієнтів кардіоревматологічного відділення НВМКЦ «ГВКГ» з діагнозом подагра. Всі хворі були 
чоловічої статі, віком від 27 до 58 років. Для дослідження вікових особливостей перебігу подагри пацієнти були розділені на дві групи: I група - 40 хворих віком до 45 років (молодий вік); II група - 52 хворих віком 46-58 років (середній вік). Для проведення дослідження і стандартизації підходу була розроблена спеціальна «Карта оцінки перебігу подагри у військовослужбовців». Результати клінічних, лабораторних та інструментальних досліджень 3 історій хвороби вносились в карту. За результатами дослідження сформована комп'ютерна база даних. Статистична обробка проводилась 3 використанням програми Microsoft Excel 2007 та стандартного статистичного пакета STATISTICA 6,0. Для змінних шкали відношень первинна обробка включала розрахунок середніх арифметичних (M), помилок середніх арифметичних (m). Для змінних найменувань та рангових змінних первинна обробка включала в себе розрахунок відсотків (Р) $(\mathrm{M} \pm \mathrm{m}) \%$. Відмінності між вибірками, оцінювались за параметричним критерієм Ст'юдента (t). Достовірність відмінностей оцінювалась за рівнем значимості $p$. Критичний рівень значимості при перевірці статистичних гіпотез у даному дослідженні приймали рівним 0,05.

Результати дослідження та їх обговорення. У розвитку подагри виділяють три періоди: преморбідний, інтермітуючий i хронічної подагри. Преморбідний період характеризується безсимптомною гіперурикемією, або (i) відходженням уратних камінців із нападами коліки, або без них. Цей період може тривати досить довго до атаки першого подагричного кризу. В інтермітуючому періоді чергуються гострі напади артриту 3 безсимптомними проміжками між ними $[1,4,8]$. Клінічний напад подагри проявляється раптовим, дуже сильним болем та набряком суглоба; в межах суглоба появляється виражена гіперемія, шкіра стає напруженою, блискучою, в підшкірній клітковині розвивається набряк; функція суглоба порушена. Рідше виявляються продромальні явища у вигляді слабкості, диспепсії, головного болю, підвищення температури. Типовий клінічний прояв подагри - ураження I плеснофалангового суглобу. Також можуть уражатись гомілковостопні, колінні суглоби, рідше суглоби верхніх кінцівок $[1,4]$.

Результати проведеного нами аналізу історій хвороби засвідчили, що на момент госпіталізації у 29 хворих діагностовано гострий подагричний артрит (першу атаку), а у 63 хворих - рецидивуючий. Розподіл військовослужбовців, хворих на подагру, в залежності від клінічної стадії представлено в табл.1.

Таблищя 1

Розподіл хворих в залежності від клінічної стадії

\begin{tabular}{|l|c|c|c|c|c|c|}
\hline \multirow{2}{*}{ Артрит } & \multicolumn{2}{|c|}{ Всього (n=92) } & \multicolumn{2}{c|}{ I група (n=40) } & \multicolumn{2}{c|}{ I група (n=52) } \\
\cline { 2 - 7 } & Абс. & $\mathbf{\%}$ & Абс. & \% & Абс. & \% \\
\hline $\begin{array}{l}\text { Гострий подагричний } \\
\text { артрит }\end{array}$ & 29 & $31,5 \pm 4,8$ & 22 & $55,0 \pm 7,9$ & 7 & $13,5 \pm 4,7^{*}$ \\
\hline $\begin{array}{l}\text { Рецидивуючий } \\
\text { подагричний артрит }\end{array}$ & 63 & $68,5 \pm 4,8$ & 18 & $45,0 \pm 7,9$ & 45 & $86,5 \pm 4,7^{*}$ \\
\hline
\end{tabular}

Примітка. * - вірогідність різниці порівняно з I групою, p<0,05

Рецидивуючий подагричний артрит достовірно частіше зустрічався у військовослужбовців II групи, а гострий - у I групі $(p<0,05)$. Типовий клінічний прояв подагри - ураження першого плеснофалангового суглоба - на момент госпіталізації військовослужбовців був лише у $40,2 \pm 5,1 \%$ хворих. Не визначено статистично достовірної різниці щодо частоти виявлення типової локалізації ураження між групами військовослужбовців, хворих на подагру,

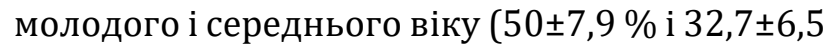
$\%$, відповідно, $\mathrm{p}>0,05)$. Таким чином, результати дослідження засвідчили, що атипова локалізація ураження визначена у
$59,8 \pm 5,1 \%$ хворих на подагру (у $50 \pm 7,9 \%$ в I групі та у 67,3ะ6,5\% в II, (p>0,05). Дослідження, проведені в 2008 році [7] визначили, що атипова локалізація ураження була у $47,4 \%$ військовослужбовців в дебюті подагри. Потребують уваги отримані нами результати щодо значної частоти ураження колінних $(23,9 \pm 4,4 \%)$ та гомілковостопних суглобів $(20,7 \pm 4,2 \%)$ у військовослужбовців, хворих на подагру, що необхідно враховувати при проведенні диференційного діагнозу суглобового синдрому. Часте ураження гомілковостопних суглобів як клінічний прояв подагри у пацієнтів середнього віку було визначено і дослідниками з Китаю [9]. 
Для подагричного артриту типовою клінічною ознакою $є$ моноартрит, особливо на початку захворювання [4, 9]. Проведений нами аналіз історій хвороби засвідчив, що ізольоване ураження першого плеснофалангового суглоба було у $25 \pm 4,5 \%$, а у $15,2 \pm 3,7 \%$ хворих визначено поєднане ураження першого плеснофалангового та інших суглобів. У хворих I групи - 35 $\pm 7,5$ \% i $15 \pm 5,6 \%$, II $-17,3 \pm 4,5 \%$ i $11,5 \pm 5,2 \%$, відповідно ( $>0,05)$. Навіть у дебюті подагри ізольоване ураження першого плеснофалангового суглоба було у $31,0 \pm 8,6 \%$, а

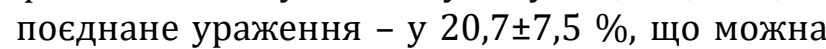
розглядати як особливість перебігу подагри на сучасному етапі. В науковій літературі $\epsilon$ поодинокі дані щодо частоти виявлення олігоартриту в дебюті у хворих на подагру Ning T.C., Keenan R.T [10] спостерігали олігоартрит тільки у $5 \%$ випадків. Важливо зауважити, що за результатами наших досліджень, поєднане ураження суглобів визначалось і у разі іншої локалізації суглобового синдрому. Так, ураження колінного суглоба було діагностовано у 23,9 $\pm 4,4 \%$ хворих: у $13,0 \pm 3,5 \%$ - ізольоване

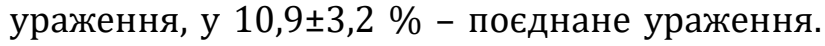

Ураження гомілкостопного суглоба - у $20,7 \pm 4,2 \%$ : у $15,4 \pm 3,8 \%$ - ізольоване ураження, 5,3 $\pm 2,3 \%$ - поєднане ураження. Таким чином, для клінічних проявів суглобового синдрому у хворих на подагру на сучасному етапі характерним $\epsilon$ поєднане ураження кількох суглобів.

У зв'язку зі значною частотою атипового перебігу суглобового синдрому у дебюті подагри виникали труднощі в діагностиці. Результати дослідження засвідчили, що діагноз подагри був виставлений при перших клінічних проявах тільки у хворих 3 класичною локалізацією ураження - у $29,3 \pm 4,7$ $\% ;$ у 70,7 $\pm 4,7 \%$ діагноз був виставлений протягом п'яти років від початкових проявів. Атиповий перебіг i дебют подагри розглядається як причина пізньої діагностики на сучасного етапі [11].

Проведено аналіз особливостей проявів суглобового синдрому у хворих 3 рецидивуючим подагричним артритом. Визначено, що ураження одного суглоба було у $42,9 \pm 6,2 \%$, двох - у 23,8 $55,4 \%$, трьох і більше у $33,3 \pm 5,9 \%$. Не визначено статистично значимої різниці міх хворими I та II групи (табл. 2).

Таблиця 2

Чисельність уражених суглобів у хворих з рецидивуючим подагричним артритом

\begin{tabular}{|l|c|c|c|c|c|c|}
\hline \multirow{2}{*}{$\begin{array}{c}\text { Ураження } \\
\text { суглобів }\end{array}$} & \multicolumn{2}{|c|}{ Всього (n=63) } & \multicolumn{2}{c|}{ I група (n=18) } & \multicolumn{2}{c|}{ II группа (n=45) } \\
\cline { 2 - 7 } & Абс. & $\mathbf{0}$ & Абс. & $\mathbf{\%}$ & Абс. & \% \\
\hline Один & 27 & $42,9 \pm 6,2$ & 8 & $44,4 \pm 11,7$ & 19 & $42,2 \pm 7,4$ \\
\hline Два & 15 & $23,8 \pm 5,4$ & 6 & $33,3 \pm 11,1$ & 9 & $20,0 \pm 6,0$ \\
\hline Три і більше & 21 & $33,3 \pm 5,9$ & 4 & $22,2 \pm 9,7$ & 17 & $37,8 \pm 7,2$ \\
\hline
\end{tabular}

Для клінічного перебігу подагри характерне прогресування: напади артриту стають частіше, інтенсивність і тривалість суглобових атак зростає, залучаються нові суглоби $[1,4]$. Результати проведеного аналізу історій хвороби засвідчили, що у більшості хворих 3 рецидивуючим подагричним артритом загострення спостерігались $1-2$ раза

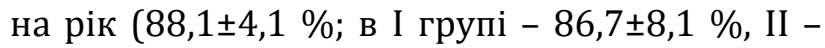

$88,9 \pm 4,7 \%$ ); один раз на рік - у 9,5 $\pm 3,7 \%$ (в I групі $-6,7 \pm 5,9 \%$; в II - 11,1 $\pm 4,7 \%$ ); три і більше

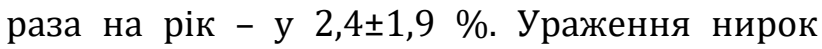
необхідно розглядати не як ускладнення подагри, а як характерний вісцеральний прояв хвороби, який нерідко вирішує долю пацієнта. Визначено, що у більшості обстежених нами хворих на подагру виявлені ураження нирок вірогідно частіше в II групі (табл. 3).

Таблиця 3

Ураження нирок у військовослужбовців, хворих на подагру

\begin{tabular}{|c|c|c|c|c|c|c|}
\hline \multirow[t]{2}{*}{ Ураження нирок } & \multicolumn{2}{|c|}{ Всього (n=92) } & \multicolumn{2}{|c|}{ I група $(n=40)$} & \multicolumn{2}{|c|}{ II група (n=52) } \\
\hline & Абс. & $\%$ & Абс. & $\%$ & Абс. & $\%$ \\
\hline $\begin{array}{l}\text { Хронічна ниркова } \\
\text { недостатність } \\
\text { (I ст.) }\end{array}$ & 33 & $35,9 \pm 5,0$ & 6 & $15 \pm 5,6$ & 27 & $51,9 \pm 6,9 *$ \\
\hline Сечосольовий діатез & 32 & $34,8 \pm 4,9$ & 7 & $17,5 \pm 6,0$ & 25 & $48,1 \pm 6,9^{*}$ \\
\hline Конкременти нирок & 17 & $18,5 \pm 4,0$ & 2 & $5 \pm 3,4$ & 15 & $28,8 \pm 6,2^{*}$ \\
\hline
\end{tabular}

Примітка. * - вірогідність різниці порівняно з І групою, $\mathrm{p}<0,05$

Таким чином, результати проведеного хворих на подагру, засвідчили зростання аналізу історій хвороби військовослужбовців, випадків атипових клінічних проявів 
суглобового синдрому, значну поширеність ураження нирок, що необхідно враховувати для вчасної діагностики i проведення лікування.

\section{Висновки}

1. Атипова локалізація ураження суглобів визначена у $59,8 \pm 5,1 \%$ військовослужбовців, хворих на подагру (у 50 7,9 \% молодого віку і у $67,3 \pm 6,5 \%$ середнього віку, p>0,05). Характерним є поєднане ураження суглобів, зокрема, першого плеснофалангового суглоба та інших суглобів, яке спостерігалось у 20,7士7,5 \% військовослужбовців в дебюті подагри.

\section{Література}

1. Дзяк Г.В., Коваленко В.Н., Хомазюк Т.А. Подагра: взгляд в будущее. К.: МОРИОН, 2020. 192 c. URL: http://repo.dma.dp.ua/id/eprint/5514

2. 2018 updated European League Against Rheumatism evidence-based recommendations for the diagnosis of gout / Richette P. et al. Ann. Rheum. Dis. 2019. Vol 79, № 1. P. 31-38. DOI: 10.1136/annrheumdis2019-215315

3. Diagnosis of Acute Gout: A Clinical Practice Guideline From the American College of Physicians / Qaseem A. et al. Ann Intern Med. 2017. Vol 166. №1. P. 52-57. DOI:10.7326/M16-0569.

4. Сучасні підходи до діагностики та ведення хворих із гострим подагричним артритом на первинному рівні медичної допомоги / Хіміон Л.В. та ін. Семейная медицина. 2016. №5 (67). С. 6-10.

5. Головач І.Ю. Сучасні рекомендації 3 менеджменту подагри. Ліки України. 2020. № 3 С. 3640. $\quad$ DOI: $\quad$ https://doi.org/10.37987/19979894.2020.3(239).214313

6. Dehlin M., Jacobsson L, Roddy E. Global epidemiology of gout: prevalence, incidence, treatment patterns and risk factors. Nat Rev Rheumatol. 2020. Vol. 16. № 7. P. 380-390. DOI: 10.1038/s41584-0200441-1

\section{References}

1. Dziak, H.V., Kovalenko, V.N., Khomaziuk, T.A. (2020). Podahra: vzghliad v budushchee. K.: MORYON, 192. Retrieved from: http://repo.dma.dp.ua/id/eprint/5514 (In Rus.).

2. Richette, P., Doherty, M., Pascual, E. et al. (2019). 2018 updated European League Against Rheumatism evidence-based recommendations for the diagnosis of gout Ann. Rheum. Dis., 79 (1), 31-38. DOI: 10.1136/annrheumdis-2019-215315

3. Qaseem, A., McLean, R. M, Starkey, M., Forciea, M. A. (2017). Diagnosis of Acute Gout: A Clinical Practice Guideline From the American College of Physicians. Ann Intern Med. 166 (1), 5257. DOI:10.7326/M16-0569.

4. Khimion, L.V., Yashchenko, O.B., Danyliuk, S.V. Sytiuk, T. O. (2016). Suchasni pidkhody do diahnostyky ta vedennia khvorykh iz hostrym podahrychnym artrytom na pervynnomu rivni medychnoi dopomohy Semeinaia medytsyna. 5 (67), 6-10. (In Ukr.).

5. Holovach, I.Iu. (2020). Suchasni rekomendatsii z menedzhmentu podahry. Liky Ukrainy. 3, 36-40. DOI:
2. Визначені проблемні аспекти ранньої діагностики подагри у військовослужбовців: при перших клінічних проявах діагноз був виставлений тільки у 29,3 $\pm 4,7 \%$ хворих 3 класичною локалізацією ураження; у $70,7 \pm 4,75 \%$ - протягом п'яти років від початкових проявів.

3. Встановлено, що у більшості хворих на подагру діагностовано ураження нирок, зокрема, хронічна ниркова недостатність виявлена військовослужбовців молодого віку та у $51,9 \pm 6,9 \%$ середнього віку, p<0,05).

7. Скляр C.I., Мороз Г.З., Тимошенко Н.О. Актуальні проблеми діагностики та лікування подагри у військовослужбовців. Сучасні аспекти військової медицини: Збірник наукових праць Головного військового клінічного центру «ГВКГ» МО України. Випуск 13. К. 2008. С. 276- 280.

8. Ragaba G., Elshahalyb M., Bardin T. Gout: An old disease in new perspective - a review. J Adv Res.2017. №8(5). P. 495-511. DOI: 10.1016/j.jare.2017.04.008.

9. Clinical characteristics of early - and lateonset gout. A cross-sectional observational study from a Chinese gout clinic / Zhang B. et al. Medicine (Baltimore). 2016. № 95(47). P. e5425. DOI: 10.1097/MD.0000000000005425

10. Ning T.C., Keenan R.T. Unusual clinical presentation of gout. Curr.Opin.Rheumatol. 2010. Vol. 22(2).

$P$. 181-

187. DOI: 10.1097/BOR.0b013e3283361ac0.

11. Рудіченко В.М., Кушнєрова М.О. Атипові прояви подагри у загальній практиці-сімейній медицині: власні клінічні спостереження та дані літератури. Семейная медицина. 2018. № 6(80). С. 2629. URL: https://fliphtml5.com/zxkp/cgep/basic

https://doi.org/10.37987/19979894.2020.3(239).214313. (In Ukr.).

6. Dehlin, M., Jacobsson, L., Roddy, E. (2020). Global epidemiology of gout: prevalence, incidence, treatment patterns and risk factors. Nat Rev Rheumatol. 16 (7), 380-390. DOI: 10.1038/s41584-020-0441-1

7. Skliar, S.I., Moroz, H.Z., Tymoshenko, N.O. (2008). Aktualni problemy diahnostyky ta likuvannia podahry u viiskovosluzhbovtsiv. Suchasni aspekty viiskovoi medytsyny: Zbirnyk naukovykh prats Holovnoho viiskovoho klinichnoho tsentru «HVKH» MO Ukrainy, 13, 276- 280.(In Ukr.).

8. Ragaba, G., Elshahalyb, M., Bardin, T. (2017). Gout: An old disease in new perspective - A review. $J$ Adv Res., 8(5), 495-511. DOI: 10.1016/j.jare.2017.04.008.

9. Zhang, B., Fang, W., Zeng X., Zhang Y., Ma Y., Sheng F., Zhang X. (2016). Clinical characteristics of early - and late-onset gout A cross-sectional observational study from a Chinese gout clinic. 
Medicine (Baltimore), 95(47), e5425. DOI: 10.1097/MD.0000000000005425

10. Ning, T.C., Keenan, R.T. (2010). Unusual clinical presentation of gout. Curr.Opin.Rheumato, 22(2), 181-187. DOI: 10.1097/BOR.0b013e3283361ac0.
11. Rudichenko, V.M., Kushnierova, M.O. (2018). Atypovi proiavy podahry u zahalnii praktytsi-simeinii medytsyni: vlasni klinichni sposterezhennia ta dani literatury Semeinaia medytsyna, 6 (80), 26-29, from: https://fliphtml5.com/zxkp/cgep/basic (In Ukr.).

\title{
КЛИНИЧЕСКИЕ ПРОЯВЛЕНИЯ ПОДАГРЫ У ВОЕННОСЛУЖАЩИХ НА СОВРЕМЕННОМ ЭТАПЕ
}

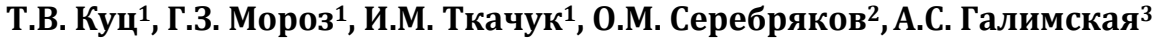 \\ 1 Украинская военно-медицинская академия, г. Киев, Украина \\ 2 Житомирский военный госпиталь, г. Житомир, Украина \\ ${ }^{3}$ Ровенский военный госпиталь, г. Ровно, Украина
}

\begin{abstract}
Цель - провести комплексный анализ клинических проявлений подагры у военнослужащих Вооруженных Сил Украины (по данным из историй болезни пациентов кардиоревматологического отделения Национального военно-медицинского клинического центра «Главный военный клинический госпиталь» (НВМКЦ «ГВКГ»).

Материалы и методы. Методом случайной выборки проведен анализ 103 историй болезни 92 пациентов мужского пола кардиоревматологического отделения НВМКЦ «ГВКГ» с диагнозом подагра, 8 возрасте от 27 до 58 лет. Для исследования возрастных особенностей течения подагры пациенты были разделены на две группы: I группа - до 45 лет (молодой возраст) 40 больных; II группа - 46-58 лет (средний возраст) 52 больных. По результатам исследования сформирована компьютерная база данных. Статистическая обработка проводилась с использованием программы Microsoft Excel $2007 \mathrm{u}$ стандартного статистического пакета STATISTICA 6,0.

Результаты. Поражение первого плюснефалангового сустава на момент госпитализации

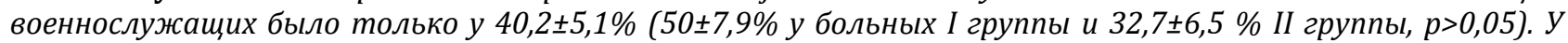
значительной части больных диагностировано поражения коленных $(23,9 \pm 4,4 \%)$ и голеностопных

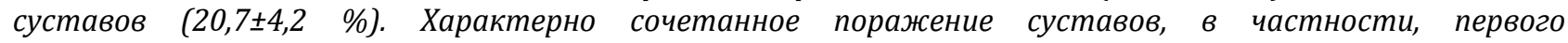
плюснефалангового сустава и других суставов, которое наблюдалось у 20,7士7,5\% военнослужащих в

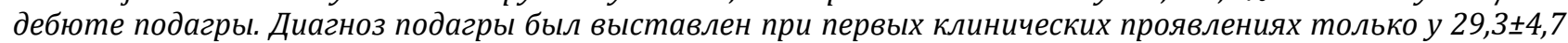
\% больных с классической локализации поражения. У большинства больных подагрой диагностировано

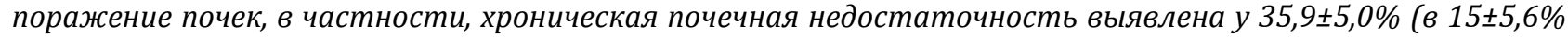

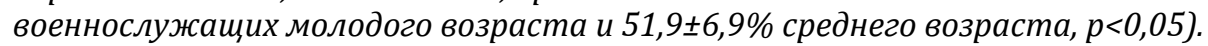

Выводы. Показано, что для большинства военнослужащих, больных подагрой $(59,8 \pm 5,1 \%)$, характерна атипичная локализация поражения суставов, частое сочетание поражения первого плюснефалангового и других суставов. При первых клинических проявлениях подагра была диагностирована только у 29,3ะ4,7\% больных. Поражение почек диагностировано у большинства больных подагрой.
\end{abstract}

Ключевые слова: подагра, суставной синдром, клинические проявления подагры

UPTODATE CLINICAL MANIFESTATIONS OF A GOUT AMONG MILITARY PERSONNEL

\author{
T.V. Kuts¹, G.Z. Moroz'1, I.M. Tkachuk ${ }^{1}$, O.M. Serebryakov², A.S. Halimska³ \\ ${ }^{1}$ Ukrainian Military Medical Academy, Kyiv, Ukraine \\ 2 Zhytomyr military hospital, Zhytomyr, Ukraine \\ ${ }^{3}$ Rivne military hospital, Rivne, Ukraine
}

The purpose: to conduct a comprehensive analysis of the clinical manifestations of gout among the military personnel of the Armed Forces of Ukraine (according to the data from the medical histories of patients of the cardio-rheumatology department of the National Military Medical Clinical Center «Main Military Clinical Hospital» (NMMCC «MMCH»).

Materials and methods. The analysis of 103 medical histories of 92 male patients of the cardiorheumatology department of the NMMCC «MMCH» with a diagnosis of gout, aged from 27 to 58 years, was carried out by the method of random sampling. To study the age-related characteristics of the course of gout, the patients were divided into two groups: group I - up to 45 years (young age) 40 patients; group II - 46-58 years (middle age) 52 patients. Based on the results of the study, a computer database was formed. Statistical processing was carried out using Microsoft Excel 2007 and the standard statistical package STATISTICA 6.0.

Results. The defeat of the first metatarsophalangeal joint was only in $40.2 \pm 5.1 \%$ of military personnel $(50 \pm 7.9 \%$ among the patients in group I and 32,7 $\pm 6.5 \%$ among the patients in group II, p $>0.05)$ at the time of hospitalization. A significant part of the patients had lesions of the knee $(23.9 \pm 4.4 \%)$ and ankle joints $(20.7 \pm 4.2 \%)$. Combined lesion of the joints, in particular, the first metatarsophalangeal joint and other joints was observed in $20.7 \pm 7.5 \%$ of the military personnel in the debut of gout. The diagnosis of gout was made at the first clinical 
manifestations only in $29.3 \pm 4.7 \%$ of patients with classical localization of the lesion. Kidney damage was diagnosed among the most patients with gout, in particular, chronic renal failure was detected in $35.9 \pm 5.0 \%$ (in $15 \pm 5.6 \%$ of young military personnel and $51.9 \pm 6.9 \%$ of middle age,p $<0,05$ ).

Conclusions. It was found that the majority among the military personnel with gout $(59.8 \pm 5.1 \%)$ had atypical localization of joint lesions, a frequent combination of lesions of the first metatarsophalangeal and other joints. It was found that gout was diagnosed only in $29.3 \pm 4.7 \%$ of patients at the first clinical manifestations. Kidney damage has been diagnosed in most patients with gout.

Key words: gout, articular syndrome, clinical manifestations of gout.

Конфлікт інтересів: відсутній.

Conflictsofinterest:authorshavenoconflictofinteresttodeclare.

\section{Відомості про авторів:}

Куц T.B.A,C,D,E,F - підполковник медичної служби, кандидат медичних наук, доцент, ТВО начальника кафедри військової загальної практики-сімейної медицини Української військово-медичної академії, м. Київ, Україна

Мороз Г.З.А,C,D,E,F - доктор медичних наук, професор, професор кафедри військової загальної практики-сімейної медицини Української військово-медичної академії, м. Київ, Україна

Ткачук I.M.C,D,E - доктор медичних наук, доцент кафедри військової загальної практики-сімейної медицини Української військово-медичної академії, м.Київ, Україна

Серебряков О.М. Е - полковник медичної служби, кандидат медичних наук, начальник Житомирського військового госпіталю, м. Житомир, Україна.

Галімська А.С. В.С,D - старший лейтенант медичної служби, ординатор терапевтичного відділення Рівненського військового госпіталю, м. Рівне, Україна.

$A$ - концепція та дизайн дослідження; $B$ - збір даних; $C$ - аналіз та інтерпретація даних;

$D$ - написання статmi; $E$ - редагування статmi; F- остаточне затвердження статті.

\section{Сведения об авторах:}

Куц Т.В. - подполковник медицинской службы, кандидат медицинских наук, доцент, ВИО начальника кафедры военной общей практики-семейной медицины Украинской военно-медицинской академии, г. Киев, Украина.

Мороз Г.3. - доктор медицинских наук, профессор, профессор кафедры военной общей практикисемейной медицины Украинской военно-медицинской академии, г. Киев, Украина.

Ткачук И.М. - доктор медицинских наук, доцент кафедры военной общей практики-семейной медицины Украинской военно-медицинской академии, г. Киев, Украина

Серебряков А.М. - полковник медицинской службы, кандидат медицинских наук, начальник Житомирского военного госпиталя., г. Житомир, Украина.

Галимская А.С. - старший лейтенант медицинской службы, ординатор терапевтического отделения Ровенского военного госпиталя, Ровно, Украина.

\section{Information about authors:}

Kuts T.V.A,C,D,E,F - LTC, MS, PHD, Associate Professor, Deputy Head of department of Military General Practice and Family Medicine of the Ukrainian Military Medical Academy, Kyiv, Ukraine. E-mail: taraskuts@gmail.com, https://orcid.org/0000-0001-7619-3679

Moroz G.Z.A,B,C,D,E,F - MD, professor, Professor of the department of Military General Practice and Family Medicine of the Ukrainian Military Medical Academy, Kyiv, Ukraine. E-mail: moroz galina@i.ua, https://orcid.org/0000-0003-4329-7193

Tkachuk I.M. ${ }^{\mathrm{C}, \mathrm{D}, \mathrm{E}}$ - MD, Associate Professor of the department of Military General Practice and Family Medicine of the Ukrainian Military Medical Academy, Kyiv, Ukraine. E-mail: iryna tkachuk@i.ua, https://orcid.org/0000-0001-6363-6821

Serebryakov O.M. ${ }^{\text {- }}$ Col, MS, PHD, Head of the Zhytomyr Military Hospital, Zhytomyr, Ukraine.

Halimska A.S. B.C,D - senior lieutenant, MS, resident of the therapeutic department of the Rivne military hospital, Rivne, Ukraine. E-mail: anna.halimska@ukr.net

$A$ - research concept and design; $B$ - collection and/or assembly of data; $C$-data analysis and interpretation;

$D$ - writing the article; $E$ - critical revision of the article; $F$ - final approval of the article.

Адреса для листування: вул. Московська, 45/1, буд. 33, м. Київ 01015 